\title{
PERLAKSANAAN PERUNDANGAN ISLAM DI MALAYSIA: SATU PENILAIAN
}

Abdul Monir Yaacob*

\begin{abstract}
This article elaborates the implementation of Islamic law in Malaysia. It includes, inter alia, the British influence in the administration of Islamic law during colonial period, the status and jurisdiction of Shariah Courts before and after Malaysia achieved independence. The article also examines the codification of Islamic Law and the interpretation to article 121 (1A) of the Federal Constitution by the Civil Courts as to whether the Syariah Courts have exclusive jurisdiction in matters which the Shariah Courts have jurisdiction. It also deals with the issue of conversion and which court has jurisdiction on this matter. The objective of the article is to show that Islamic Law was the law of the land since the Malay Sultanate ruled Malacca. The British interference in the administration of Islamic justice has reduced its application to only personal matters. The position of Shariah Courts after the Court Ordinance 1948 came with effect. The purpose of article 121 (1A) of the Federal Constitution is to avoid conflict of jurisdiction between Civil Courts and Syariah Courts. The role of Shariah and Civil laws Technical Committee in drafting new laws for the Shariah Courts. From the overview of the development of
\end{abstract}

Datuk Dr, Felow Penyelidik Kanan, Jabatan Syariah dan Undangundang, Akademi Pengajian Islam, Universiti Malaya. 
Islamic Law in Malaysia there are other areas which need reforms. In the concluding part several recommendations were suggested for consideration.

Keywords : Islamic Law, Development of Shariah Courts, The Administration of Islamic Law Enactment, Article 121(1A), Cases on Conversion, The Shariah and Civil Laws Technical Committee.

\section{PENDAHULUAN}

Telah banyak sekali penulisan yang telah dihasilkan oleh tokohtokoh tanah air mengenai perlaksanaan perundangan Islam di Malaysia seperti penulisan Allahyarham Profesor Tan Sri Ahmad Mohammad Ibrahim dan ahli-ahli yang pakar dalam bidang undang-undang dan syariah termasuk ahli akademik dan profesional yang tidak perlu dinyatakan nama-nama mereka. Begitu juga dengan seminar-seminar yang menyentuh perkara yang sama di merata tanah air. JAKIM, IKIM, JKSM dan pusatpusat pengajian tinggi adalah di antara institusi-institusi yang telah banyak menganjurkan perbincangan dan seminar-seminar tentang perundangan Islam di Malaysia. Dalam perbincangan dan seminarseminar termasuk persidangan telah begitu banyak pandangan, teguran dan cadangan bagi mengemaskini dan meningkatkan lagi perlaksanaan perundangan Islam di Malaysia.

Di antara isu yang disentuh dalam penulisan mengenai tajuk ini adalah pengaruh penjajahan Inggeris yang kuat dalam menentukan pentadbiran dan perlaksanaan hukum syarak di negara ini. Catatan dan fakta sejarah menunjukkan bahawa negara ini semasa pemerintahan Kesultanan Melayu Melaka dan di negeri-negeri Melayu sebelum dijajah oleh Inggeris telah melaksanakan hukum syarak dengan berpandukan kepada teks-teks Melayu Lama yang termuat di dalamnya hukum syarak, ${ }^{1}$ hanya aspek yang tertentu sahaja yang diterima dalam perundangan negara. Bahkan dalam kes Ramah lwn Laton', Mahakamah Rayuan Negeri-negeri

\footnotetext{
$1 \quad$ Ahmad Ibrahim \& Ahilemah Joned (2005), Sistem Undang-undang di Malaysia. Kuala Lumpur: Dewan Bahasa dan Pustaka, hh.49-50. 2 (1927) 6 FMSLR. 128.
} 
Melayu Bersekutu memutuskan bahawa undang-undang Islam bukanlah undang-undang asing tetapi undang-undang tempatan dan undang-undang negara. Tidaklah menjadi tujuan kertas ini untuk menjelaskan bagaimana Inggeris memandang sepi kepada hukum syarak. Cukup diutarakan pendapat seorang orientalis yang mengatakan bahawa perundangan Islam dibuat sepertimana undang-undang lain melalui enakmen.

\section{PERUNDANGAN ISLAM DALAM ZAMAN PENJAJAH}

Dalam memahami perlaksanaan hukum syarak di Malaysia, ia tidak boleh disamakan perlaksanaannya dengan negara-negara Islam yang lain. Setiap negara Islam mempunyai pendekatannya tersendiri. Malaysia mempunyai dua pendekatan dalam perlaksanaan hukum syarak. Pertama dengan tidak memberikan kuatkuasa undang-undang dan kedua dengan perundangan yang boleh dikuatkuasa oleh mahkamah. Kebanyakan tuntutan hukum syarak dilaksanakan oleh orang Islam tanpa kuatkuasa undangundang seperti berkaitan dengan sembahyang dan haji.

Yang dimaksudkan dengan pendekatan perundangan iaitu hukum syarak yang dikanunkan oleh badan perundangan atau 'Legislative Council'. Sebelum negara mencapai kemerdekaan terdapat beberapa enakmen yang berkaitan dengan perundangan Islam seperti tentang perkahwinan dan beberapa kesalahan syariah.

Apa yang dilihat menunjukkan bahawa Inggeris walaupun dalam pelbagai teriti dengan Raja-raja Melayu menyatakan dengan jelas bahawa Raja-raja Melayu bersetuju menerima semua nasihat Inggeris kecuali dalam hal ehwal mengenai agama Islam dan adat istiadat Melayu. Bagaimanapun, secara langsung atau tidak langsung Inggeris telah banyak campur tangan dalam hal ehwal pentadbiran agama Islam. Akibatnya hukum syarak hanyalah terpakai dalam undang-undang keluarga, perwarisan dan beberapa aspek jenayah syariah. ${ }^{3}$ Beberapa undang-undang yang dipakai di India telah diterima pakai. ${ }^{4}$ Bahkan apabila Inggeris menduduki Pulau Pinang mereka telah memberi gambaran salah tentang

Ahmad Ibrahim \& Ahilemah Joned (2005), op.cit., h. 51.

Ibid., h. 83. 
fakta. ${ }^{5}$ Sir Benson Maxwell menjelaskan kedudukan Pulau Pinang sehingga pengistiharan Piagam Keadilan 1807 dalam kes Regina lwn Willans ${ }^{6}$ menyatakan :

"It is clear beyond all doubt not for the first twenty years and upwards of its history, no body of known law was in fact recognized as the law of the place"

Begitu juga dengan pentadbiran hukum syarak pada permulaannya jawatan naib kadi dan kadi telah diiktiraf dengan menubuhkan Mahkamah Kadi dan Mahkamah Naib Kadi di negerinegeri Melayu dalam struktur Mahkamah Awam. Kedudukannya lebih rendah dari Mahkamah Majistret, walaupun berada dalam struktur mahkamah yang sama. Akhirnya apabila diadakan Ordinan Mahkamah 1948 bagi menubuhkan sistem kehakiman bagi Persekutuan, Mahkamah Naib Kadi dan Mahkamah Kadi telah diabaikan dengan mengeluarkannya daripada hierarki Mahkamah Persekutuan dan hari ini dikenali dengan Mahkamah Syariah dan mempunyai status mahkamah negeri dengan bidang kuasa amat rendah dan terbatas.

Beberapa tahun sebelum Persekutuan Tanah Melayu mencapai kemerdekaan pada 31 Ogos 1957 ada dua peristiwa penting yang berlaku iaitu penubuhan Suruhanjaya Reid untuk menderaf Perlembagaan Persekutuan dan kedua pengkanunan Undang-undang Pentadbiran Hukum Syarak 1952 bagi negeri Selangor. Enakmen ini telah menjadi model bagi pentadbiran perundangan Islam di negara ini. Akhirnya setiap negeri telah mengadakan enakmen Pentadbiran Hukum Syarak masingmasing. Enakmen ini mempunyai 180 seksyen dan kandungannya menyentuh penubuhan Majlis Agama Islam, perlantikan Mufti dan Jawatankuasa Fatwa, undang-undang Islam berkaitan dengan perkahwinan dan perceraian, nafkah, penjagaan anak, keterangan, prosedur jenayah dan sivil, perwarisan, pembahagian harta sepencarian, wakaf dan nazar, zakat dan fitrah dan Baitulmal, pengurusan masjid, pemelukan agama Islam, wasiat dan beberapa kesalahan matrimoni dan kesalahan yang boleh dihukum ta'zir. Enakmen Pentadbiran Hukum Syarak 1952 ini ada membuat peruntukan bagi penubuhan Mahkamah Kadi dan Kadi Besar dan

\footnotetext{
$5 \quad$ Regina lwn Willans (1858) 3 Ky.16.

6 Ibid.
} 
bidang kuasanya. Rayuan dibuat ke Jawatankuasa Ulangbicara. Pelantikan Kadi dan Kadi Besar dan anggota panel Rayuan. Enakmen ini telah dipinda beberapa kali dan yang terakhir pada tahun 2003 dengan nama Enakmen Pentadbiran Agama Islam, negeri Selangor 2003. Beberapa pindaan penting telah dibuat kepada Undang-undang Pentadbiran Agama Islam seperti penyusunan semula Mahkamah Syariah dan pengwujudan jawatanjawatan Hakim-hakim Mahkamah Syariah termasuk Ketua Hakim Syarie. Perubahan ini juga berlaku di negeri-negeri lain, termasuk Wilayah Persekutuan. Pada hari ini struktur Mahkamah Syariah di negara ini adalah seragam.

\section{PERUNDANGAN ISLAM SELEPAS KEMERDEKAAN}

Terdapattiga institusiyang terlibatdalamperlaksanaan perundangan Islam iaitu Majlis Agama Islam, Mufti, dan Mahkamah Kadi (Mahkamah Syariah). Bagaimanapun, dalam artikel ini hanya akan menyentuh aspek perundangan Islam yang ditadbir oleh Mahkamah Syariah dan yang telah dikanunkan oleh badan perundangan iaitu Parlimen dan Dewan Perundangan Negeri. Undang-undang pentadbiran perundangan Islam yang dipakai oleh negeri-negeri termasuk Wilayah-wilayah Persekutuan telah mengalami beberapa pindaan dan tujuannya adalah untuk menjadikannya lebih lengkap dan relevan. Perlembagaan Persekutuan dalam Jadual Kesembilan Senarai 2, Senarai Negeri menyatakan perkara-perkara berhubung dengan hukum syarak yang terletak pada Badan Perundangan Negeri untuk menggubalnya termasuk kuasa menubuhkan Mahkamah Syariah yang mempunyai bidang kuasa hanya ke atas orang Islam. Mahkamah tersebut tidak boleh mempunyai bidang kuasa mengenai kesalahan-kesalahan kecuali setakat yang diberi oleh undang-undang Persekutuan. Terdapat banyak undang-undang Persekutaun yang menghadkan bidang kuasa dan pemakaian undang-undang negeri, ${ }^{7}$ seperti Akta Mahkamah Syariah (Bidang kuasa Jenayah) 1965 (Disemak) 1984. Pindaan 1984 memberi kuasa kepada Mahkamah Syariah, selain denda tidak lebih lima ribu ringgit dan penjara tidak lebih tiga tahun, termasuk sebatan tidak lebih enam sebatan, begitu juga dalam

Ahmad Mohamad Ibrahim (1997), Pentadbiran Undang-undang Islam di Malaysia. Kuala Lumpur: IKIM. 
pentadbiran pusaka dihalang oleh Akta Probet dan Pentadbiran 1959 (Disemak) (1972) dan Akta Pusaka Kecil (Pembahagian) 1955 (Disemak) (1972).

Allahyarham Profesor Ahmad Ibrahim dalam satu penulisannya bertajuk Ke arah Islamisasi Undang-undang di Malaysia ada menyenaraikan dengan lengkap undang-undang Persekutuan yang perlu dipinda bagi tujuan memberi bidang kuasa yang lebih luas atau bagi menghapuskan campur tangan Mahkamah Sivil. Di antara undang-undang tersebut ${ }^{8}$ iaitu Akta Probet dan Pentadbiran, Akta Penjagaan Kanak-Kanak 1961, Akta Perempuan Bersuami dan Kanak-Kanak (Penguatkuasaan Nafkah) 1968, Akta Timbangtara, Seksyen 112 Akta Keterangan mengenai kesahtarafan anak. Seksyen 100 yang memperuntukkan bahawa sesuatu wasiat hendaklah ditafsirkan di Melaka, Pulau Pinang, Sabah dan Sarawak mengikut tafsiran undang-undang Inggeris. Seksyen 51 Akta Memperbaharui Undang-Undang (Perkahwinan dan Perceraian) 1976 dan Akta Pemegang Amanah 1949 kerana wakaf dianggap sebagai amanah di bawah akta tersebut walaupun terdapat pindaan Perlembagaan seperti memasukkan perkataan "Mahkamah Syariah" dalam Perkara 5, begitu juga dalam undangundang lain pun perkataan "mahkamah" hendaklah ditafsir supaya termasuk Mahkamah Syariah seperti dalam Akta Polis. ${ }^{9}$

Bagi memberi penggunaan yang lebih meluas kepada hukum syarak, Akta Undang-undang Sivil 1956 perlu dipinda iaitu Mahkamah Sivil hendaklah diberi kuasa mengadakan dan mengikut Common Law Malaysia ${ }^{10}$ yang boleh diubahsuaikan dengan rujukan kepada hukum syarak. ${ }^{11}$

Pada masa sekarang, bidang kuasa jenayah terikat dengan Akta Mahkamh Syariah (Bidangkuasa Jenayah) 1965 (Pindaan) 1984, yang menghadkan kuasa Mahkamah Syariah. Akta Mahkamah

8 Ahmad Ibrahim, (1996), 'Pindaan Undang-undang Bertulis' dalam Abdul Monir Yaacob \& Sarina Othman, (eds), Tinjauan Kepada Perundangan Islam. Kuala Lumpur: IKIM, h.33.

$9 \quad$ Ibid., hh. 33-35.

10 Pada suatu ketika, langkah telah diambil oleh Kementerian Kehakiman Malaysia bagi membincangkan isu tersebut. Pada ketika itu YB Dato' Seri Syed A. Hamid Albar adalah menteri di kementerian tersebut.

11 Ahmad Ibrahim (1996), op.cit., hh. 33-34. 
Syariah (Bidangkuasa Jenyah) (Pindaan) 1984 menghadkan bidang kuasa Mahkamah Syariah dalam menjatuhkan hukuman penjara tidak lebih tiga tahun atau denda tidak melebihi lima ribu ringgit atau sebat tidak lebih enam sebatan atau kombinasi manamana hukuman itu.

Bidang kuasa ini masih rendah atau sempit jika dibandingkan dengan bidang kuasa Mahkamah Majistret Kelas Pertama. Akta Mahkamah Rendah 1948 memberi bidangkuasa jenayah kepada Mahkamah Majistret Kelas Pertama menjatuhkan hukuman sehingga sepuluh tahun penjara atau rotan 12 kali atau gabungan kedua-dua. Bagi membolehkan Mahkamah Syariah menjatukan hukuman yang lebih berat dan denda yang lebih tinggi maka Akta tersebut perlulah dipinda, bahkan telah sampai masanya berbuat demikian. Pindaan pertama dibuat setelah hampir dua puluh tahun dan kini telah dua puluh lima tahun Akta tersebut tidak dikaji semula.

Bidang kuasa Jenayah dan Mal yang diberikan kepada Mahkamah Syariah ada diperuntukan dalam Enakmen Pentadbiran Perundangan Islam negeri-negeri. Ada perkara di mana Mahkamah Syariah mempunyai bidang kuasa akan tetapi tidak semua negeri mempunyai undang-undang yang khusus dan terperinci seperti mengenai wakaf, wasiat dan zakat. Bahagian hukum syarak yang diperbuat peruntukan yang agak jelas dan menyeluruh adalah mengenai kekeluargaan, bagaimanapun masih belum lengkap. Bahkan ada pihak yang tidak berpuashati tentang beberapa peruntukan seperti seksyen 23 mengenai poligami dan seksyen 58 pembahagian harta sepencarian apabila berlaku poligami. Dengan perkembangan masa adalah difikirkan perlu untuk membuat kajian bagi mengemaskini undang-undang yang sedia ada dan untuk mewujudkan undang-undang yang relevan bagi seluruh negerinegeri. Oleh kerana pegangan madhhab di kalangan penduduk Islam pada umumnya sama iaitu Madhhab Sunni yang lebih tertumpu kepada aliran Madhhab Syafi'i sudah sepastinya tidak ada masalah untuk mengadakan keseragaman tersebut.

Langkah pertama telah diambil oleh kerajaan Persekutuan untuk mengadakan satu model undang-undang bagi pentadbiran Undang-undang Keluarga Islam. Justeru sebuah jawatankuasa telah dibentuk bagi menggubal undang-undang tersebut. Apabila 
draf undang-undang itu siap ia telah dihantar kepada Majlis Rajaraja. Setelah dipersetujui draf ini dihantar kepada tiap-tiap negeri untuk diterima dan dilaksanakan. Pihak berkuasa negeri telah menubuhkan jawatankuasa bagi meneliti draf tersebut, seperti di negeri Kedah, Kelantan dan Wilayah Persekutuan. Sungguhpun niat dan tujuan asal adalah untuk menyelaraskan atau untuk mengadakan satu undang-undang Keluarga Islam yang seragam di antara negeri-negeri, akan tetapi hasrat ini akhirnya tidak tercapai dan perbezaan-perbezaan masih berlaku. ${ }^{12}$

Dengan usaha tersebut akhirnya lahirlah Enakmen UndangUndang Keluarga Islam 1983, Kelantan, Akta Undang-undang Keluarga Islam (Wilayah-Wilayah Persekutuan) 1984 dan Enakmen Undang-undang Keluarga Islam 1984, Kedah. Negerinegeri lain telah mengadakan Enakmen Keluarga Islam yang serupa dengan mengambil contoh dari negeri-negeri tersebut.

Seperti yang telah dijelaskan, setiap negeri mempunyai Enakmen Pentadbiran Undang-undang Islam (dengan nama yang berbeza) dikanunkan pada tahun yang berbeza. Selangor 1952, Sarawak 1954, Pahang 1956, Melaka 1959, Pulau Pinang 1959, Negeri Sembilan 1960, Kedah 1962, Perlis, 1964, Perak 1965, Kelantan 1966, Wilayah Persekutuan1974, Sabah 1977 dan Johor 1978. Enakmen-enakmen tersebut bertujuan menyatukan dan meminda undang-undang pentadbiran agama Islam berkaitan dengan penubuhan, penyusunan, dan pentadbiran agama Islam dan Mahkamah Syariah di negeri-negeri. Walaupun tidak lengkap akan tetapi lebih jelas dan mudah untuk dibuat rujukan berbanding sebelumnya. Sebelum diadakan Enakmen pentadbiran tersebut, undang-undang mengenai agama Islam telah dibuat oleh "State Council" dalam bentuk "Order in Council" oleh negeri-negeri berkenaan. Sebagai contoh Enakmen Perkahwinan dan Perceraian Orang-orang Islam, Perak 1900 dan ia terpakai bagi orang-orang Islam sahaja. Enakmen ini telah mewujudkan jawatan Kadi Besar di Perak. ${ }^{13}$ Bagaimanapun Enakmen itu dipinda dari masa ke semasa. Pengalaman yang berlaku di negeri Perak, berlaku juga

12 Ahmad Ibrahim \& Ahilemah Joned (2005), op.cit., hh. 67-68.

13 Mohamad Asri bin Haji Abdullah, Sistem Pentadbiran Undang-undang Islam di Negeri Perak, Dahulu dan Sekarang, JH, 1998, h.158. 
kepada negeri-negeri Melayu yang lain terutama bagi negerinegeri Melayu Bersekutu (FMS).

Enakmen lain yang perlu disebut di sini iaitu Enakmen Majlis Agama Islam dan Adat Melayu. Setiap negeri ada enakmen seumpama ini seperti Council of Religion and Malay Custom Enactment 1949, Selangor, Enakmen Majlis Agama Islam dan Adat Melayu Perak, 1951. Enakmen ini antara lain membuat peruntukan tentang penyusunan Majlis Agama Islam dan kuasa yang diberikan kepadanya. Enakmen tersebut kemudiannya telah dimansuhkan oleh Enakmen Pentadbiran Agama Islam negerinegeri yang terbaharu.

Setelah negara mencapai kemerdekaan, usaha telah dibuat bagi meningkat dan mengemaskinikan lagi pentadbiran agama Islam. Ada negeri yang telah mengambil langkah dengan menubuhkan jawatankuasa bagi mencapai tujuan tersebut. Bahkan ada pihak yang menghantar rombongan keluar negara untuk mengambil pengalaman tentang pentadbiran undang-undang Islam di beberapa negara Islam.

\section{PERKEMBANGAN UNDANG-UNDANG ISLAM}

Undang-Undang adalah sesuatu yang hidup dan berkembang mengikut keperluan dan kemajuan yang dicapai dalam sesebuah masyarakat. Dalam kaedah fiqh ada menyatakan, "hukum itu berubah dengan perubahan masa, keadaan dan tempat". Ini adalah suatu kenyataan dan contoh yang paling jelas berlaku dalam perkembangan Fiqh Syafi'i dengan adanya qawl qadim dan qawl jadid.

Perubahan dan perkembangan perundangan Islam di Malaysia berlaku secara beransur-ansur. Bahkan pada suatu tempoh yang lama, langsung tiada perkembangan atau perubahan. Ada negeri dalam tempoh tiga puluh tahun tiada perkembangan yang penting berlaku. Enakmen Pentadbiran Hukum Syarak 1952 Selangor hanya dipinda pada tahun $1989^{14}$ dan dalam tempoh tersebut hanya bahagian mengenai perkahwinan telah dipinda dengan mengadakan Enakmen Undang-undang Keluarga Islam 1984.

14 Enakmen Pentadbiran Perundangan Islam, Selangor 1989. 
Tahun lapan puluhan adalah merupakan tahun reformasi Undangundang Keluarga Islam di Malaysia. Perubahan telah berlaku di peringkat negeri. Kedah, 1979(1984); Kelantan, 1983; Melaka, 1983; Negeri Sembilan, 1983; Wilayah Persekutuan, 1984; Perak, 1984; Pulau Pinang, 1985; Terengganu, 1985; Pahang, 1987 dan Sarawak, 1991. Ada beberapa negeri telah membuat pindaan pada undang-undang tersebut seperti Kelantan (1985 \& 1987); Selangor, 1988 dan Johor 1990. Mutakhir ini kita dapati isu telah ditimbulkan berhubung dengan Undang-undang Keluarga Islam yang baru yang telah dibentangkan dalam Parlimen. Isu-isu yang ditimbulkan adalah menyentuh seksyen 23, Poligami dan seksyen 58 mengenai harta sepencarian.

Dalam tahun lapan puluhan, perubahan bukan sahaja berlaku kepada pentadbiran Undang-undang Keluarga Islam akan tetapi kepada bahagian-bahagian lain Enakmen Pentadbiran Hukum Syarak. Perundangan Persekutuan yang menyekat bidangkuasa Mahkamah Syariah di negara ini turut dipinda. Akta Mahkamah Syariah (Bidang kuasa Jenayah) 1965 yang menyatakan bidang kuasa Mahkamah Syariah dalam perkara jenayah syariah telah dipinda dalam tahun 1984 dengan Akta Mahkamah Syariah (Bidang kuasa Jenayah) (Pindaan) 1984. Dengan pindaan ini, bidang kuasa Mahkamah Syariah dalam kes-kes jenayah telah dinaikkan. Kedua, Perkara 121 Perlembagaan Persekutuan telah dipinda oleh Akta Perlembagaan (Pindaan) 1988 Akta A704 dengan mengadakan peruntukan baru iaitu Fasal 1 (1A). Fasal ini menyatakan : "mahkamah-mahkamah yang disebut dalam Fasal (1) tidaklah boleh mempunyai bidang kuasa berkenaan dengan apa-apa perkara dalam bidang kuasa Mahkamah Syariah".

Mengikut Allahyarham Profesor Ahmad Ibrahim:

"Satu kesan yang terbesar yang diperolehi dari pindaan itu ialah mengelakkan percanggahan antara keputusan Mahkamah Syariah dan Mahkamah Tinggi seperti yang terdapat di dalam beberapa kes terdahulunya". ${ }^{15}$

Sebelum pindaan tersebut Mahkamah Tinggi ada bidang kuasa memutuskan perkara-perkara dalam bidang kuasa Mahkamah

15 Ahmad Ibrahim (Prof.) (1991), Pindaan Kepada Perkara 121 Perlembagaan Persekutuan dan Kesannya kepada Pentadbiran Undang-undang Islam, JH, h. 129. 
Syariah seperti dalam perkara penjagaan anak, wakaf dan harta sepencarian. Pindaan tersebut telah memulihkan maruah dan taraf Mahkamah Syariah dan ia tidak lagi dipandang begitu rendah berbanding dengan Mahkamah Sivil. Mahkamah Syariah boleh dikatakan telah dibebaskan daripada gangguan Mahkamah Sivil. ${ }^{16}$ Pada hakikatnya taraf Mahkamah Syariah boleh dianggap masih rendah dan Mahkamah Sivil masih menerima kes-kes yang bidang kuasa sememangnya terletak pada Mahkamah Syariah seperti dalam kes Dalip Kaur lwn Pegawai Polis Daerah, Balai Polis Daerah Bukit Mertajam. ${ }^{17}$ Dalam kes tersebut Mahkamah memutuskan bahawa Mahkamah Sivil mempunyai bidang kuasa selagi tiada undang-undang negeri yang memberi bidang kuasa kepada Mahkamah Syariah. Bagi mengatasi masalah percanggahan bidang kuasa antara Mahkamah Syariah dan Mahkamah Tinggi, Prof Ahmad Ibrahim berpendapat masih ada terdapat undangundang bertulis yang lama yang perlu dipinda untuk mengelakkan apa-apa keraguan.

Satu lagi pindaan yang penting ialah kepada Perkara 5 Perlembagaan Persekutuan. Dengan ini dalam hal penangkapan bagi sesuatu kesalahan yang boleh dibicarakan oleh Mahkamah Syariah sebutan-sebutan dalam Fasal ini mengenai seorang Majistret hendaklah ditafsirkan sebagai termasuk seorang hakim Mahkamah Syariah. Dengan pindaan ini telah menyamakan kuasa hakim Mahkamah Syariah dalam perkara itu dengan kuasa Majistret. ${ }^{18}$

Ketika negara mencapai kemerdekaan, kedudukan Mahkamah Syariah masih rendah dan tertakluk kepada keputusan Mahkamah Sivil. Memandang betapa perlunya tarafdan kedudukan Mahkamah Syariah dan hakim-hakimnya ditingkatkan, maka kerajaan telah menubuhkan sebuah Jawatankuasa Petugas dan ia dipengerusikan oleh Allahyarham Tan Sri Syed Nasir Ismail. Jawatankuasa ini telah membuat beberapa perakuan dan cadangan, di antaranya:

1. Mengasingkan Mahkamah Syariah, Majlis Agama Islam dan Jabatan Agama Islam

Ibid., h. 134.

17 (1992) MLJ 1; Lina Joy lwn Majlis Agama Islam Wilayah Persekutuan (2007) , 4MLJ, 585.

18 Ahmad Ibrahim (1996), op.cit,. h.137. 
2. Menyusun sistem kehakiman Mahkamah Syariah dan mengambil langkah meluaskan bidang kuasa Mahkamah Syariah dan taraf serta kedudukan hakim-hakimnya.

Cadangan-cadangan tersebut telah diterima oleh Majlis Rajaraja dan kerajaan untuk dilaksanakan. Beberapa negeri telah mengambil langkah melaksanakan cadangan-cadangan tersebut seperti Kedah, Kelantan, Melaka dan Wilayah Persekutuan. ${ }^{19}$ Pada peringkat ini, struktur Mahkamah Syariah negeri-negeri mengikut Enakmen Mahkamah Syariah Kedah 1983 iaitu Mahkamah Kadi dan Mahkamah Rayuan. Kadi Besar adalah pengerusi Mahkamah Rayuan. Baginegeri Kelantan, Enakmen Mahkamh Syariah Kelantan 1982, mahkamah adalah Mahkamah Rayuan Syariah, Mahkamah Kadi Besar, Mahkamah Kadi Khas dan Mahkamah Kadi Jajahan. Pengerusi Mahkamah Rayuan adalah mufti. Susunan Mahkamah Syariah di negeri-negeri pada umumnya adalah Mahkamah Rayuan Syariah, Mahkamah Kadi Besar dan Mahkamah-mahkamah Kadi Daerah. Mufti adalah pengerusi Mahkamah Rayuan Syariah. Beberapa negeri telah memindanya seperti Kedah dengan mengadakan Enakmen Mahkamah Syariah 1993 dengan struktur baru iaitu menubuhkan Mahkamah Rendah Syariah, Mahkamah Tinggi Syariah dan Mahkamah Rayuan Syariah. ${ }^{20}$

Langkah juga telah diambil untuk mengemaskinikan undangundang keterangan dan acara yang dipakai oleh Mahkamah Syariah. Peruntukan yang terdapat dalam Enakmen Pentadbiran Hukum Syarak yang lama di negeri-negeri adalah amat ringkas dan tidak mengikut Hukum Syarak. Bagi menyediakan undangundang tersebut, rujukan juga dibuat kepada undang-undang acara dan keterangan yang dipakai di Mahkamah Sivil. Beberapa negeri telah menyediakan undang-undang acara mal dan acara jenayah syariah seperti berikut ${ }^{21}$ :

1. Enakmen Acara Jenayah, Kelantan 1983

2. Enakmen Acara Sivil, Kelantan 1984

3. Enakmen Acara Mal Islam, Kedah 1979

\footnotetext{
$19 \quad$ Ibid., h.247.

20 Seksyen 3, Enakmen Mahkamah Syariah, Kedah 1993.

21 Ahmad Ibrahim, Ke Arah Perlaksanaan Undang-undang Islam, h. 267.
} 
Negeri-negeri lain telah mengambil langkah yang sama untuk menyediakan Enakmen Acara Mal, Enakmen Acara Jenayah Syariah dan Enakmen Keterangan Mahkamah Syariah. Dalam menggubal Enakmen Keterangan ini, rujukan telah dibuat kepada Akta Keterangan 1960. Cadangan undang-undang Keterangan Islam yang dibuat oleh Hakim Tanzilul Rahman dan Majlis Ideologi Islam Pakistan dan Kanun Shahadat Pakistan. Draf undang-undang tersebut telah digubal oleh Jawatankuasa Hukum Syarak, Wilayah Persekutuan. Di antara hasil yang ketara daripada perakuan yang dibuat oleh Jawatankuasa mengkaji kedudukan Mahkamah-mahkamah Syariah adalah penyusunan semula struktur Mahkamah Syariah kepada tiga peringkat iaitu :

1. Mahkamah Rayuan Syariah

2. Mahkamah Tinggi Syariah

3. Mahkamah Rendah Syariah

Pada hari ini semua Mahkamah-mahkamah Syariah di seluruh Malaysia telah mengadakan peruntukan dalam undang-undang negeri berkenaan bagi penyusunan semula Mahkamah-mahkamah Syariah di negeri masing-masing kepada tiga peringkat. Usaha juga telah dibuat bagi penubuhan Jabatan Kehakiman Syariah negerinegeri dengan Ketua Hakim Syarie sebagai ketua pentadbiran. Begitu juga dengan penubuhan Jabatan Kehakiman Syarie Malaysia (JKSM) yang diterajui oleh Ketua Hakim Syarie/Ketua Pengarah di peringkat Persekutuan. Orang yang pertama dilantik ke jawatan tersebut adalah YAA Datuk Sheikh Ghazali bin Abdul Rahman. Jawatan itu sekarang disandang oleh YAA Tan Sri Datuk Ibrahim Lembut.

\section{PENYELARASAN UNDANG-UNDANG ISLAM}

Kaedah bagi penyelarasan undang-undang ada diperuntukkan oleh Perlembagaan Persekutuan. Mengikut Perkara 76(1)(b), Parlimen boleh membuat undang-undang mengenai apa-apa perkara yang disebutkan dalam Senarai Negeri termasuk undang-undang Islam bagi maksud mengadakan persamaan undang-undang di antara dua buah negeri atau lebih. Undang-undang yang dibuat ini akan dikenakan kepada orang-orang Islam di sesuatu negeri dan apabila 
diterima dengan suatu undang-undang yang diperbuat oleh Badan Perundangan Negeri. Selepas itu, undang-undang ini hendaklah disifatkan sebagai undang-undang yang dibuat oleh Badan Perundangan Negeri. ${ }^{22}$

Raja adalah ketua agama bagi negeri-negeri yang mempunyai Sultan dan Yang Dipertuan Agung bagi negeri-negeri yang tidak mempunyai Sultan dan bagi Wilayah-wilayah Persekutuan. Ini ada diperuntukkan dalam Perlembagaan Persekutuan. ${ }^{23}$ Bagaimanapun Perkara 160 Perlembagaan Persekutuan tidak memasukkan dengan nyata tentang undang-undang Islam apabila memberi tafsiran kepada undang-undang. Dalam Jadual Kesembilan, Senarai 2 Senarai Negeri, Perlembagaan Persekutuan ada menyenaraikan perkara-perkara menyentuh hukum syarak dan pentadbirannya termasuk penubuhan Mahkamah Syariah dan menyediakan dan menghukum kesalahan-kesalahan yang dilakukan oleh orang-orang yang menganut Islam terhadap rukun-rukun Islam, kecuali mengenai perkara-perkara yang termasuk dalam Senarai Persekutuan. Begitu juga mengadakan undang-undang bagi mengawal pengembangan iktikad dan kepercayaan antara orangorang yang menganut Islam. ${ }^{24}$

Perkara 11 (4) menyatakan :

"Undang-undang Negeri dan mengenai Wilayah-Wilayah Persekutuan Kuala Lumpur, Labuan dan Putrajaya, undangundang Persekutuan boleh mengawal atau menyekat pengembangan apa-apa iktikad atau kepercayaan ugama antara orang-orang yang menganuti ugama Islam."

Bagaimanapun tidak semua negeri termasuk Wilayah Persekutuan yang menggunakan peruntukan tersebut dan tiada undang-undang diperbuat bagi tujuan perkara 11(4) ini. Pendakwaan dalam kes melanggar undang-undang seumpama itu dibuat di Mahkamah Sivil bukan Mahkamah Syariah kerana melibatkan pihak-pihak bukan Islam.

22 Perkara 76(3).

23 Perkara 3(2), 3(3), 3(5).

24 Ada beberapa negeri telah membuat undang-undang bagi tujuan tersebut seperti Kelantan dan Pahang, bagaimanapun perlaksanaannya oleh Mahkamah Sivil. Seperti Enakmen Kawalan dan Sekatan Penyebaran Agama-Agama Bukan Islam (Pahang) 1989. 
Di peringkat kebangsaan telah ditubuh Jawatankuasa Teknikal Undang-undang Syarak dan Sivil. Ia ditubuhkan pada pertengahan tahun 1988. Prof Tan Sri Ahmad Ibrahim, pada ketika itu Sheikh Kuliyyah Undang-undang, Universiti Islam Antarabangsa Malaysia telah dilantik sebagai pengerusi. Di antara tujuan penubuhan jawatankuasa ini adalah untuk mengkaji undang-undang yang sedang dipakai oleh Mahkamah Syariah dan menyediakan undang-undang yang baru yang lebih kemas dan lengkap di samping mengemaskininya. Dalam beberapa tahun, Jawatankuasa ini telah membuat semakan kepada beberapa undang-undang dan menyediakan draf undang-undang yang baru untuk dipakai oleh Mahkamah Syariah. ${ }^{25}$

Jawatankuasa ini juga telah berjaya membuat semakan kepada beberapa undang-undang Islam yang ditadbirkan oleh Mahkamah Syariah termasuk Enakmen Pentadbiran Perundangan Islam, Enakmen Undang-undang Keluarga Islam, Enakmen Pentadbiran Mahkamah Syariah dan Enakmen Kesalahan Jenayah Syariah. Jawatankuasa ini telah mendraf beberapa undang-undang untuk dipakai oleh Mahkamah Syariah seperti Enakmen Acara Mal Mahkamah Syariah, Enakmen Kanun Prosedur Jenayah Syariah, Enakmen Keterangan Mahkamah Syariah, Enakmen Wasiat, Wakaf, Zakat dan Fitrah. Hampir keseluruhan perundangan tersebut telah diterima oleh negeri-negeri dalam tahun sembilan puluhan. ${ }^{26}$

Perkembangan yang terkini sekali, walaupun telah memakan masa yang lama adalah untuk menyelaraskan enam enakmen utama yang dipakai oleh Mahkamah Syariah termasuk Enakmen Pentadbiran Perundangan Islam dan Enakmen Undang-undang Keluarga Islam. Cadangan undang-undang baru ini telah dimasukkan dalam mesyuarat Majlis Raja-raja untuk perkenan raja-raja. Satu jawatankuasa telah ditubuhkan untuk meneliti kesemua draf undang-undang tersebut. Pada peringkat permulaan,

25 Lihat Abdul Monir Yaacob (t.t), "Pengkanunan Undang-undang Islam di Malaysia", dalam Khairul Azmi Muhammad \& Abdul Monir Yaacob (eds.), Perlaksanaan Hukum Syarak di Malaysia. Johor Bharu: Pejabat Menteri Besar Johor, h.70.

26 Contoh, Akta Keterangan Mahkamah Syariah (Wilayah Persekutuan) Akta 561, 1997, Johor (1993), Melaka (1991), Enakmen Pentadbiran Undang-undang Islam, (1991), Pahang, Melaka, (1991). 
dua draf undang-undang telah ditangguhkan iaitu draf Undangundang Pentadbiran Perundangan Islam dan draf Undang-undang Kesalahan Syariah. Mengenai dengan draf Undang-undang Pentadbiran, negeri-negeri diberi kelonggaran untuk meminda draf tersebut untuk disesuaikan dengan kehendak dan keadaan semasa pentadbiran agama Islam negeri masing-masing; justeru tidaklah dapat diseragamkan sepenuhnya Undang-undang Pentadbiran Perundangan Islam di negara ini. Mengenai dengan draf undangundang Kesalahan Syariah terdapat teguran dari kabinet dan ia telah ditangguhkan untuk semakan selanjutnya.

Boleh disimpulkan hasrat untuk menyeragamkan semua undangundang yang dipakai oleh Mahkamah Syariah di negara ini hampir tercapai sepenuhnya. Kebanyakkan negeri telah menerima draf undang-undang tersebut. Contohnya negeri Johor telah menerima dan mengkanunkan Enakmen Tatacara Mal Mahkamah Syariah 2003, Enakmen Keterangan Mahkamah Syariah 2003 dan Enakmen Undang-undang Keluarga Islam 2003. Dengan demikian telah meminda enakmen-enakmen terdahulu dalam tajuk yang sama. ${ }^{27}$ Langkah yang sama telah diambil oleh kebanyakan negeri termasuk Selangor. ${ }^{28}$

Beberapa negeri telah menerima draf Undang-undang Keluarga Islam termasuk negeri Melaka. ${ }^{29}$ Apabila Rang Undang-undang Keluarga Islam (Wilayah-Wilayah Persekutuan) dibentangkan di Parlimen, beberapa isu telah ditimbulkan oleh beberapa ahli Parlimen wanita. Ini adalah kerana ada rasa tidak puas hati di kalangan NGO. Secara khususnya mempersoalkan pindaan seksyen 23(3) - poligami tentang perkataan "patut atau perlu" sedangkan dalam Akta Undang-undang Keluarga Islam (Wilayahwilayah Persekutuan) 1984 seksyen 23(3) menggunakan perkataan "patut dan perlu". Isu yang kedua adalah menyentuh harta sepencarian yang terdapat dalam seksyen 58, Akta Undangundang Keluarga Islam yang lama. Adalah difahamkan cadangan

27 EnakmenKanun Prosedur Jenayah Syariah 1997(dimansuhkan), Enakmen Keterangan Mahkamah Syariah 1993 (dimansuhkan), Enakmen Undangundang Keluarga Islam 1990 (dimansuhkan), Enakmen Pentadbiran Agama Islam 1978, beberapa seksyen dimansuhkan, lihat seksyen 248.

28 Enakmen Keterangan Mahkamah Syariah, Selangor 2003. Enakmen Tatacara Jenayah Syariah, Selangor 2003.

29 Enakmen Undang-undang Keluarga Islam 2002, Melaka. 
supaya peruntukan-peruntukan tersebut dipinda telah diambil tindakan oleh pihak JAKIM.

Isu yang masih hangat diperkatakan oleh masyarakat sekarang adalah tentang pertukaran agama. Isu pertukaran agama khususnya "murtad" adalah perkara lama yang pernah dibangkitkan dalam tahun lapan puluhan lagi seperti dalam kes Re Susie Teoh ${ }^{30}$, dan setelah itu Mahkamh Sivil telah mendengar beberapa kes murtad atau permohonan pertukaran agama. ${ }^{31}$

Pendapapat YA Hakim Abdul Hamid Muhamad dalam kes Lim Chan Seng dan seorang lagi perlulah diberi perhatian. Hakim itu berpendapat ;

"Untuk memberi bidangkuasa itu kepada Mahkmah Syariah, Badan Perundangan Negeri kenalah membuat undang-undang mengenainya"

Kini ada negeri yang membuat peruntukan prosedur untuk keluar dari agama Islam iaitu Negeri Sembilan, seperti dalam seksyen 90A Enakmen Pentadbiran Hukum Syarak, 1991. Dengan mengambil perhatian terhadap teguran YA Hakim tersebut dan keputusan beberapa kes oleh Mahkamah Sivil mengenai permohonan keluar Islam, akhirnya satu peruntukan telah ditambah kepada bidangkuasa Mal Mahkamah Syariah. Di antara peruntukan baru yang diadakan dalam Enakmen Pentadbiran Agama Islam Negeri Selangor, 2003 iaitu seksyen 61(3)(b)(x) dan (xi) adalah seperti berikut :

(x) pengistiharan bahawa seseorang itu bukan lagi orang Islam; dan

(xi)pengistiharan bahawa seseorang yang telah mati itu adalah seorang Islam atau sebaliknya pada masa kematiannya.

Peruntukan-peruntukan tersebut tiada dalam Enakmen Pentadbiran Hukum Syarak, negeri Selangor 1989. Terdapat

30 (1986) 2 MLJ 229; (1990) 2 MLJ 206.

31 Majlis Agama Islam Negeri Sembilan lwn Hun Mun Meng (1992) 2 MLJ 276; Lim Chan Seng dan seorang lagi lwn Pengarah Jabatan Agama Islam, Pulau Pinang (1996) 3 CLJ 231; Soo Singh lwn Perkim Kedah (1994) 1 MLJ 690; Md. Hakim Lee lwn Majlis Agama Islam Wilayah Persekutuan (1998) 1 MLJ 681. 
beberapa negeri yang belum membuat pindaan. Ini adalah peruntukan baru, akibat daripada beberapa keputusan yang dibuat oleh Mahkamah Sivil yang memutuskan bahawa Mahkamah Syariah mempunyai bidangkuasa bagi mengistiharkan bahawa seseorang itu bukan lagi orang Islam. ${ }^{32}$ Dengan adanya peruntukan-peruntukan itu dapat membantu Mahkamah Syariah bagi membuat keputusan ke atas permohonan keluar agama Islam. ${ }^{33}$ Isu pertukaran agama adalah suatu yang rumit untuk diselesaikan kerana beberapa isu lain akan timbul apabila satu pihak disahkan menukar agamanya; kesan yang paling nyata adalah ke atas nafkah isteri dan anak-anak, penjagaan kanak-kanak dan pembahgian harta.

\section{KESIMPULAN}

Secara umumnya dapat disimpulkan bahawa perlaksanaan Hukum Syarak di negara ini mempunyai asas dan latar belakang yang kukuh dan telah dilaksanakan sejak penubuhan kerajaan Melayu Melaka dan berterusan sehingga ke zaman penjajah dengan penyempitan pelaksanaan Hukum Syarak. Penjajah British telah memberi bentuk baru dalam pentadbiran Hukum Syarak di negara ini iaitu dengan memperkenalkan dalam bentuk perundangan.

Apabila negara mencapai kemerdekaan, Islam telah diberi kedudukan dalam Perlembagaan dan raja telah diberi status ketua agama. Perlembagaan juga telah memberi bidang kuasa kepada Badan Perundangan Negeri bagi membuat perundangan Islam di dalam batas-batas yang telah ditetapkan oleh Perlembagaan dan tertakluk kepada Perundangan Persekutuan yang juga membatas pelaksanaan sepenuhnya Hukum Syarak.

Bagi memberi bidang kuasa yang lebih luas kepada Badan Perundangan Negeri untuk mengkanunkan Hukum Syarak yang lebih meluas, pandangan-pandangan yang telah banyak diberikan oleh tokoh-tokoh perundangan negara sama ada dalam bentuk

32 Soon Singh a/l Bikar Singh lwn Pertubuhan Kebajikan Islam Malaysia (PERKIM) Kedah \& Anor (1999) 2 AMR 1221; Lina Joy lwn Majlis Agama Islam Wilayah Persekutuan (2007), 4MLJ, 585.

33 Dalam Perkara Permohonan Keluar Islam Muhammad Ramzan Maniarason (Pahang) JH Jld XXI, Bhg II, hh.181-189. 
penulisan atau pandangan yang dikeluarkan dalam persidangan perlulah diambil perhatian dan dilaksanakan dengan mengambil kira situasi semasa, seperti meminda Akta Mahkamah Syariah (Bidangkuasa Jenyah)(Pindaan) 1984, dengan meningkatkan bidangkuasanya seperti bidangkuasa Jenayah yang ada pada Mahkamah Sesyen.

Bagi memberi imej Islam yang lebih menonjol, perlulah diwujudkan Jabatan Ifta yang diketuai oleh Mufti Negara. Kebanyakan negara Islam mempunyai mufti bagi negaranya. Islam adalah agama bagi Persekutuan maka perlulah ada mufti bagi Persekutuan. Isu menyentuh Hukum Syarak yang bersifat nasional telah timbul dari masa ke semasa, maka telah sampai masanya ditubuhkan Bahagian Peguam Cara Syarie Negara. Penubuhan unit Syariah di Jabatan Peguam Negara boleh dijadikan landasan tersebut.

Kedudukan Mahkamah Syariah buat masa ini telah diberi kedudukan yang lebih baik berbanding di zaman penjajah. Bagaimanapun pembaikan, peningkatan dan pemantapan masih ada ruang. Justeru Mahkamah Syariah perlulah disusun semula dan diberi kuasa yang lebih besar dan menyeluruh. Begitu juga kakitangan mahkamah yang terlatih dan mencukupi. Satu Perkhidmatan Perundangan dan Kehakiman Syarak patut ditubuhkan. Mahkamah Syariah patut disusun semula dengan menubuhkan Mahkamah Agung Syariah. Dengan demikian akan terdapat dua peringkat rayuan. Status Hakim-hakimnya ditingkatkan.

Penyelarasan undang-undang Islam telah diusahakan dan ramai pihak telah terlibat. Perundangan Islam perlu dikaji dari masa ke semasa dan dikanunkan supaya Mahkamah Syariah dan orang ramai lebih mudah mengetahui dan mentadbirnya.

Ada perkara yang tidak disentuh dalam perbincangan kertas ini tetapi ia penting disebutkan iaitu mengenai Perbankan dan Kewangan Islam, Takaful dan Pasaran Modal Islam. Walaupun tidak dikanunkan dalam Akta Pentadbiran Hukum Syarak, namun perjalanannya adalah mengikut prinsip syarak kerana ia dipantau oleh Majlis Syariah di peringkat Bank Negara, Suruhanjaya Sekuriti dan penubuhan Jawatankuasa Syariah di institusi berkenaan. Apabila timbul pertikaian ia di bawa ke Mahkamah Sivil untuk 
diselesaikan. Oleh kerana pelanggan kepada produk-produk tersebut terdiri dari semua lapisan masyarakat tanpa mengira agama maka adalah lebih praktikal ditubuhkan "Syariah Bench" di peringkat Mahkamah Rayuan dan Mahkamah Persekutuan bagi mendengar dan meyelesaikan kes-kes rayuan dalam isu-isu tersebut ini. Permohonan tidak boleh dibuat di Mahkamah Syariah kerana perkara yang berkaitan dengannya adalah di bawah kuasa perundangan persekutuan dan Mahkamah Syariah tiada bidang kuasa, apabila satu pihak itu bukan Islam. Adalah diharapkan pandangan-pandangan yang dikemukakan dalam penulisan ini mendapat perhatian dan dilaksanakan. Semoga dapat menaikkan lagi kedudukan Hukum Syarak di negara ini. 